\title{
Process Flowcharting: A Skill That Adds Value
}

Vijay Karan (E-mail: vkaran@fullerton.edu), California State University Fullerton Zafar Khan (E-mail: zafar.khan@emich.edu), Eastern Michigan University

Mohsen Sharifi, Ph.D., C.M.A. (E-mail: msharifi@ fullerton.edu), California State University Fullerton

\begin{abstract}
The education gap between important required skills and the competence level of accounting recruits in corporations has been reported to be the largest for skills such as ability to understand the business and familiarity with "business processes." To alleviate this gap the starting point is the accounting curriculum. One skill that should prove valuable is an ability to analyze and reengineer business processes. Process flowcharting or process mapping facilitates analysis and eventually design and/or reengineering of the operations and process under study. This paper recommends and promotes process mapping as one of the value adding skills that should be included in accounting curricula to close the gap between accounting graduates competencies and the demands of the profession. Three examples of possible assignments are presented in this paper that may be suitable for presentation to students at different levels in the accounting curriculum.
\end{abstract}

\section{Introduction}

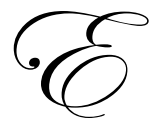

mployers today are demanding not only more but also varied knowledge, skills, and abilities from the graduates of accounting programs (Siegel, Kulezsa, and Sorensen, 1997). The American Institute of Certified Public Accountants (AICPA 1988 \& 2000), the Bedford Committee (AAA Bedford 1986), the "White Paper" (Arthur Andersen et al. 1989) and the Accounting Education Change Commission (AECC 1990) have all stated the need for improvement in the quality of graduates of accounting programs. The International Association places similar expectations on business programs for Management Education (formerly the AACSB) and other regional accreditation bodies such as the North Central Association of Colleges and Schools and the Southern Association of Colleges and Schools (AAA 1993).

The "education gap" between important required skills and the competence level of accounting recruits in corporations has been reported to be the largest for skills such as the ability to "understand the business" and familiarity with "business processes" (Siegel, Kulesza, and Sorensen, 1997). To implement the recommendations of the interested groups, a starting point is the accounting curriculum. There are many questions asked by leaders of accounting programs and faculty. Among those questions: What subjects are relevant to the career path of accounting graduates? What subjects or skills should be introduced in the accounting curriculum? What is the appropriate depth and breadth of knowledge and skills to be introduced?

One skill that should prove valuable is an ability to analyze and reengineer business processes (Bradford, M., Roberts, D., and Stroupe, G., 2001). Process flowcharting or process mapping facilitates analysis, evaluation, and eventually the design and/or reengineering of the operations and processes under study. Furthermore as CPA's advance into higher managerial positions and strategic responsibilities they find that their communication is greatly facilitated by employing graphical presentations such as flowcharting (Lehman, 2000). The question remains as to how much time and effort should be placed on this particular skill given the array of competing skills that are demanded from accounting programs in general and in accounting information systems courses in particular. This paper recommends and promotes process mapping as one of the value adding skills that should be included in accounting curricula to close this gap between accounting graduates competencies and the demands of the profession.

Readers with comments or questions are encouraged to contact the authors via email. 
Three examples of possible assignments are presented in this paper that may be suitable for presentation to students at different levels in the accounting curriculum. Some simple productivity tools used to draw and facilitate a more effective learning of process maps are also listed.

\section{Why Business Process Analysis is Important?}

It is increasingly being acknowledged that a better understanding of information systems and operations would create more value for accounting graduates. The need for process analysis as one of the desired skills for accounting graduates has been emphasized in many recent accounting publications. The Mock Committee has pointed out the importance of process analysis in a form of topical coverage based on a survey using a scaled ranking system (AAA, 1987). Many of the top skills ranked by accounting professionals in the Albrecht and Sack report (2000) imply process analysis skills. The Institute of Management Accountants has identified process analysis as required knowledge for future Management Accountants. The most recent AICPA's Core Competency Framework for Entry into the Accounting Profession (2000) identifies a set of functional, personal and broad business competencies for all students preparing to enter the newly envisioned accounting profession. Lists of those competencies that totally or partially require process analysis skills are shown in Exhibit 1. The skills listed require understanding of decision processes, in particular Resource Management skills listed under the Broad Business Perspective Competencies. The need for introduction of business process analysis is more apparent even in public accounting practice where consulting has become a greater source of revenue generated.

Accountants in the private sector can act as valuable members of management teams and help in revamping the internal processes by cutting down unnecessary overhead and eliminating redundant efforts. They also can help in implementing the balanced scorecard systems driven by innovative processes resulting in customer satisfaction and consequently superior financial performance (Kaplan, R.S., and Norton, D.P., 1996). All these activities thrive on the understanding of processes, analysis of those processes, and eventually designing or innovating new processes. Furthermore, design of a product development process, creation of an effective quality system, implementing an adequate customer relation management process, and running a useful financial information system, all require intimate knowledge of processes that run these types of systems. Process mapping is also the engine behind "predictive accounting" which ties future financial performance to the organization's processes (Marshall). Streamlining the internal processes appears to be just the beginning of the journey. The supper efficient organizations are extending their boundaries beyond reducing costs, enhancing quality and speeding of the internal processes. They are working with partners and suppliers to design and manage processes across corporate boundaries (Hammer).

\section{Process Flowcharting}

To make the graduate of accounting programs more marketable close attention should be given to the core competencies and practice analysis described in Exhibit 1. Many of the skills listed under Personal Competencies and Broad Business Perspective Competencies require understanding of processes. It is imperative that our graduates understand the process under study if we expect them to evaluate and propose alternative solutions; articulate the way organizations make decisions to allocate scarce resources; how those resources affect business functions and processes; and the implications of an organization's lack of access to supply sources and many other similar situations.

The integration of popular enterprise systems (ES) into an AIS course places additional demand on the process analysis skill. Although many of the instructors emphasize working knowledge of the software package, the serious challenge for the accounting graduates is to implement those packages in the real world back office environments that are effectively designed and reengineered first. This should serve as a solution for generic implementation of ES packages that have resulted in many unsuccessful rollouts. To avoid this pitfall the organization must first study its processes. This is normally done by first flowcharting the processes under scrutiny and optimizing the process before introducing the software in the organization.

To be responsive to the recommendations of AECC and AICPA many schools emphasize understanding of business processes in their accounting systems courses. Process mapping and flowcharting would facilitate the understanding of the systems being discussed. 
Exhibit 1

Core Competencies Requiring Process Analysis Skills

\begin{tabular}{|c|c|}
\hline FUNCTIONAL & \\
\hline \multirow[t]{2}{*}{ Decision Modeling } & Identifies problems and potential solution approaches \\
\hline & Link data, knowledge, and insights together for decision-making purposes \\
\hline \multicolumn{2}{|l|}{ PERSONAL } \\
\hline \multirow{2}{*}{$\begin{array}{l}\text { Problem Solving and Decision Mak- } \\
\text { ing }\end{array}$} & Adapts to new contexts and promotes constructive change \\
\hline & Proposes and evaluates alternative solution \\
\hline Leadership & $\begin{array}{l}\text { Organize and effectively displays information so that it is meaningful to the receiv- } \\
\text { ing party }\end{array}$ \\
\hline \multirow[t]{6}{*}{ Project Management } & Effectively facilitates and controls the project \\
\hline & Measure project progress \\
\hline & Takes corrective action as needed \\
\hline & Sees projects through to completion or orderly transition \\
\hline & Realistically estimates time and resource requirements \\
\hline & $\begin{array}{l}\text { Recognizes situation where prompt and determined actions are needed and responds } \\
\text { accordingly }\end{array}$ \\
\hline \multicolumn{2}{|l|}{$\begin{array}{l}\text { BROAD } \\
\text { TIVE }\end{array}$} \\
\hline \multirow[t]{3}{*}{ Strategic/Critical Thinking } & $\begin{array}{l}\text { Identifies strengths, weaknesses, opportunities, and threats associated with a } \\
\text { specific scenario, case, or business activity }\end{array}$ \\
\hline & $\begin{array}{l}\text { Identifies and gathers data from a wide variety of sources to provide insightful } \\
\text { interpretations for decision-making }\end{array}$ \\
\hline & Analyzes and prepares strategic information \\
\hline \multirow[t]{2}{*}{ Industry/Sector Perspective } & $\begin{array}{l}\text { Recognizes market forces that make a given organization a candidate for merger, } \\
\text { acquisition, and/or strategic alliance }\end{array}$ \\
\hline & $\begin{array}{l}\text { Communicates the financial and nonfinancial performance of an organization's } \\
\text { operational processes }\end{array}$ \\
\hline \multirow[t]{5}{*}{ Resource Management } & $\begin{array}{l}\text { Articulates how resource availability affects the organization's business functions, } \\
\text { processes, and administrative procedures }\end{array}$ \\
\hline & $\begin{array}{l}\text { Identifies both traditional and non-traditional performance criteria and measurement } \\
\text { methods by selecting appropriate success factors and measures of their achievement }\end{array}$ \\
\hline & $\begin{array}{l}\text { Articulates how organizations make decisions to allocate scarce resources, includ- } \\
\text { ing recognition of both quantitative and qualitative constraints on these decisions }\end{array}$ \\
\hline & $\begin{array}{l}\text { Analyzes the implications of an organization's lack of access to supply sources, } \\
\text { financial markets, and intellectual capital }\end{array}$ \\
\hline & $\begin{array}{l}\text { Facilitates analysis of the organization and the application of continuous improve- } \\
\text { ment principles to the organization }\end{array}$ \\
\hline
\end{tabular}

To understand business processes, one must first analyze them. Flowcharting is a tool traditionally used for studying the system under investigation and proposing a new design when applicable. In this section we will discuss why process flowcharting is important and where we need to emphasize this skill. In discussing this premise the authors have studied several introductory information systems textbooks.

Three types of graphical presentations of the system under study are generally discussed in information systems courses. They are document flowchart, systems flowchart, and data flow diagram. Document flowcharts depict the flow of documents (often physical) between and within areas of responsibility of an organization. It has been utilized predominately by auditors in evaluating the movement of documents, adequacy of internal accounting checks, segregation of duties and overall effectiveness of an internal control system. The number of symbols used in this type of flowcharting is limited to a few. Some accounting or consulting firms have created their own proprietary symbols to make this type of flowcharting more effective.

System flowchart is a logical presentation of information as processed by the information system. It emphasizes processing by depicting the type of inputs, outputs, and storages utilized in order to accomplish the goals of the information systems. The symbols used are more than those for document flowcharts. Most professionals use the symbols recommended by the American National Standards Institute. 
The third type of graphical presentation is a data flow diagram (DFD). DFD is the presentation of data flows within a system, disregarding the type of input, output and storage mediums used in the process, i.e. they only represent how the data elements are moved and processed within an entity. The number of symbols used to create DFD is only four.

In addition to the three types of graphical representations mentioned above, other graphical depiction are also used, however, not to the same extent. Among them are hardware and program flowcharts and Entity - relationship (ER) diagrams, although the latter is not a flowchart, it is presented in many textbooks for drawing schemas and sub-schema of conceptual data models.

Until recently, process flowcharting had not been discussed in any accounting information systems textbooks. However, it is gradually finding its way to textbooks as one of the effective methods of describing systems (Moscove, 2001). The main question is how much time we must devote to this skill in the context of total skill set that we introduce to our accounting students.

\section{Suggested Solution}

We recommend a larger share for process flowcharting in the accounting curriculum. This could be accomplished by placing more weight on process mapping in the typical AIS course. Of course this places an added pressure onto an already crowded course. The second approach is to create a separate home in the curriculum for the introduction of this skill. The second approach may be more effective if appropriate materials are developed first. Present AIS textbooks have spent little or no effort in describing this valuable skill.

To accomplish this we must realize that process mapping is one of the most effective methods used to describe what is being done in an organization. To improve quality, increase profit, reduce cost, enhance the process, and expedite what is being done we must first understand the process.

We present three types of assignments that are appropriate for different levels of exposure to the subject. The first assignment is an introductory one, appropriate for sophomore/junior level courses. The second assignment is targeted toward senior level students by allowing them to apply knowledge gained in cost management courses in a form of Activity-Based Costing implementation project. The third assignment is designed for senior/graduate students. It applies process mapping and process flowcharting to a strategic problem, in particular a merger and acquisition (M \& A) decision.

\section{First assignment}

In the first assignment the objective is to introduce the concept of process mapping. Students, individually or in teams, are asked to flowchart the morning chore, a process followed by individuals every morning. The basic process flowcharting symbols shown in Exhibit 2 are used.

To draw the flowchart of this process the team must first identify activities within the chore process. A process is defined as a sequence of activities or tasks that converts input to output. To draw this process a parallelogram is used to represent the inputs and outputs of each activity. A rectangle is used to represent the activities. A diamond represents the decision points and all the elements of the flowchart are connected to each other using lines pointed with an arrow (Galloway). The team could choose to make this process as sophisticated and detailed as they would like to manage. For instance the team may draw each activity of shampooing, washing and drying hair separately or combined. However they are reminded that anytime more details are added to the process they may have to spend resources such as time and money to control those activities. In real world cases, anytime more activities within a process are identified greater stress is placed on the information system. That is, someone must collect and report information about the additional activities identified. Students, it is hoped, will learn that it is best to identify those activities that consume most of the resources. This is refereed to as $20-80$ rule (20\% of activities use $80 \%$ of resources). 


\section{Exhibit 2}

Business Process Mapping Symbols

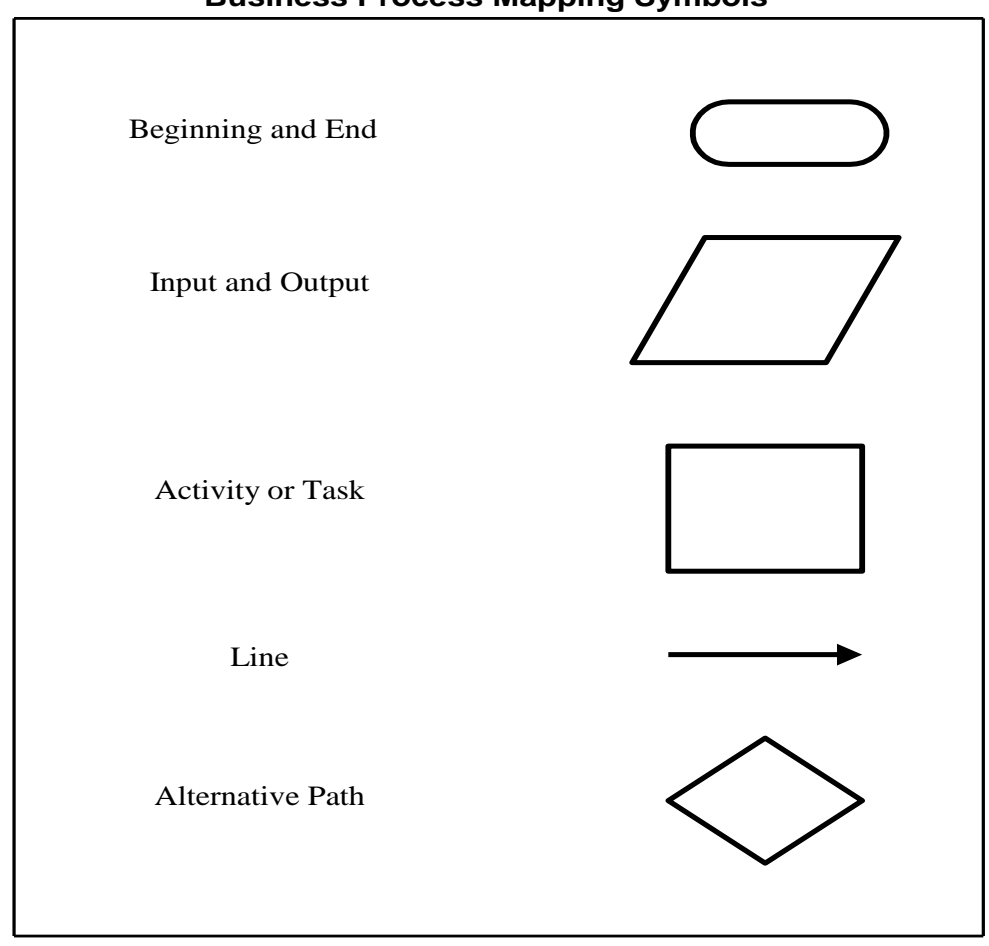

In drawing this flowchart they are reminded to follow some basic rules.

- Be clear of what is being flowcharted i.e., a process, an activity, a task, etc.

- Make sure to draw those activities that are "actually performed" and not "desired to be performed"

- Start at the top left corner of a clear sheet.

- Draw a clear, neat, and easy to understand chart and avoid crossed lines

- May cross-refer the flowchart to other flowcharts. That is, an activity could be further exploded to subactivities or tasks.

Exhibit 3 depicts one possible version of the morning chore. Explosion of "Apply make-up/shave" activity is shown in Exhibit 4.

In both flowcharts, all activities are represented by rectangles. Diamonds are used to depict alternative paths in the process. Diamond normally offers two paths: a true path and a false path. A flowcharting convention is to use the words "Yes" and "No" to represent these paths. It is possible to have more than two paths branch out of a given diamond. This assignment will provide the team with enough skill to handle more realistic business processes. 


\section{Exhibit 3}

Morning Chore Process

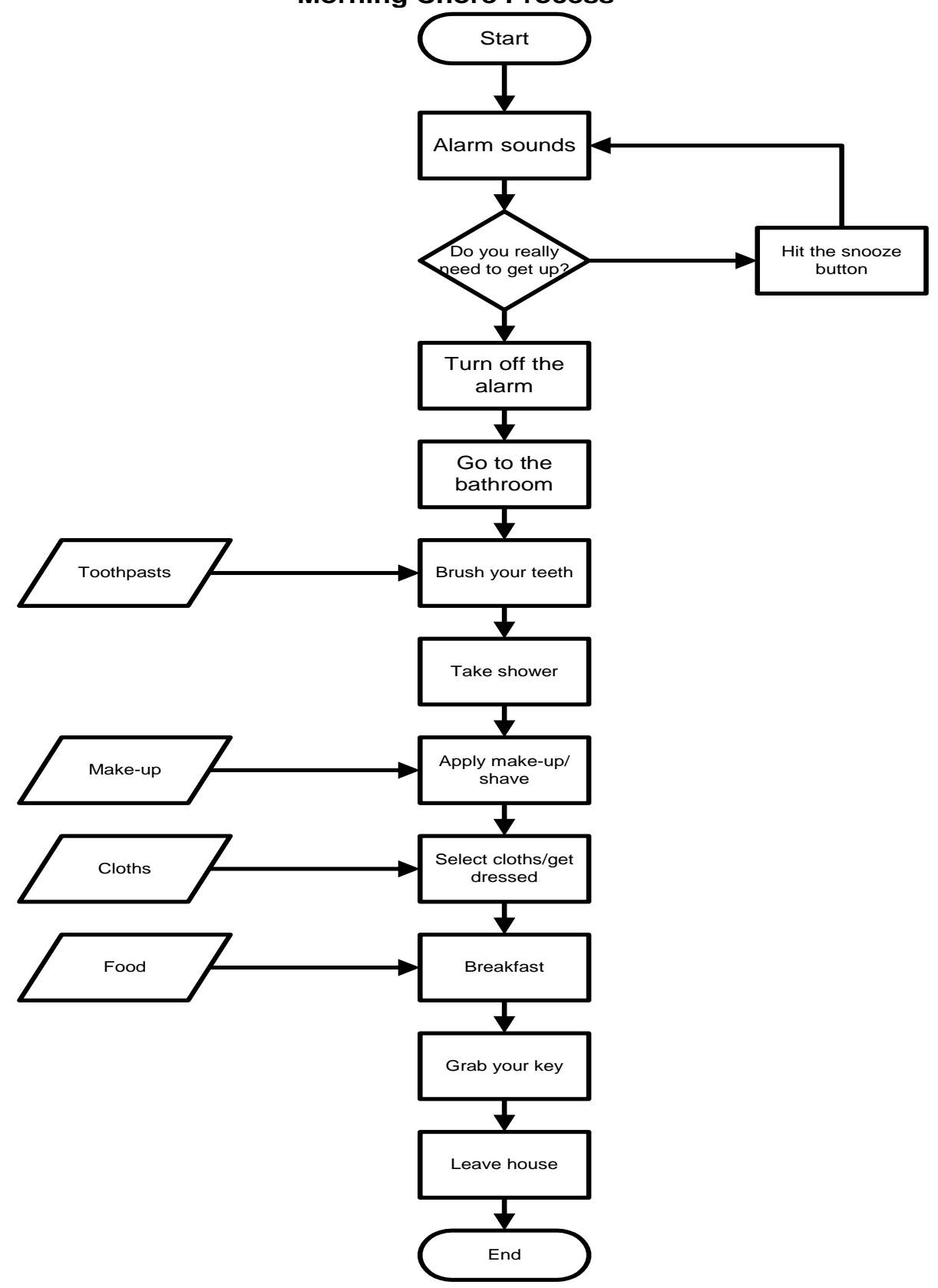




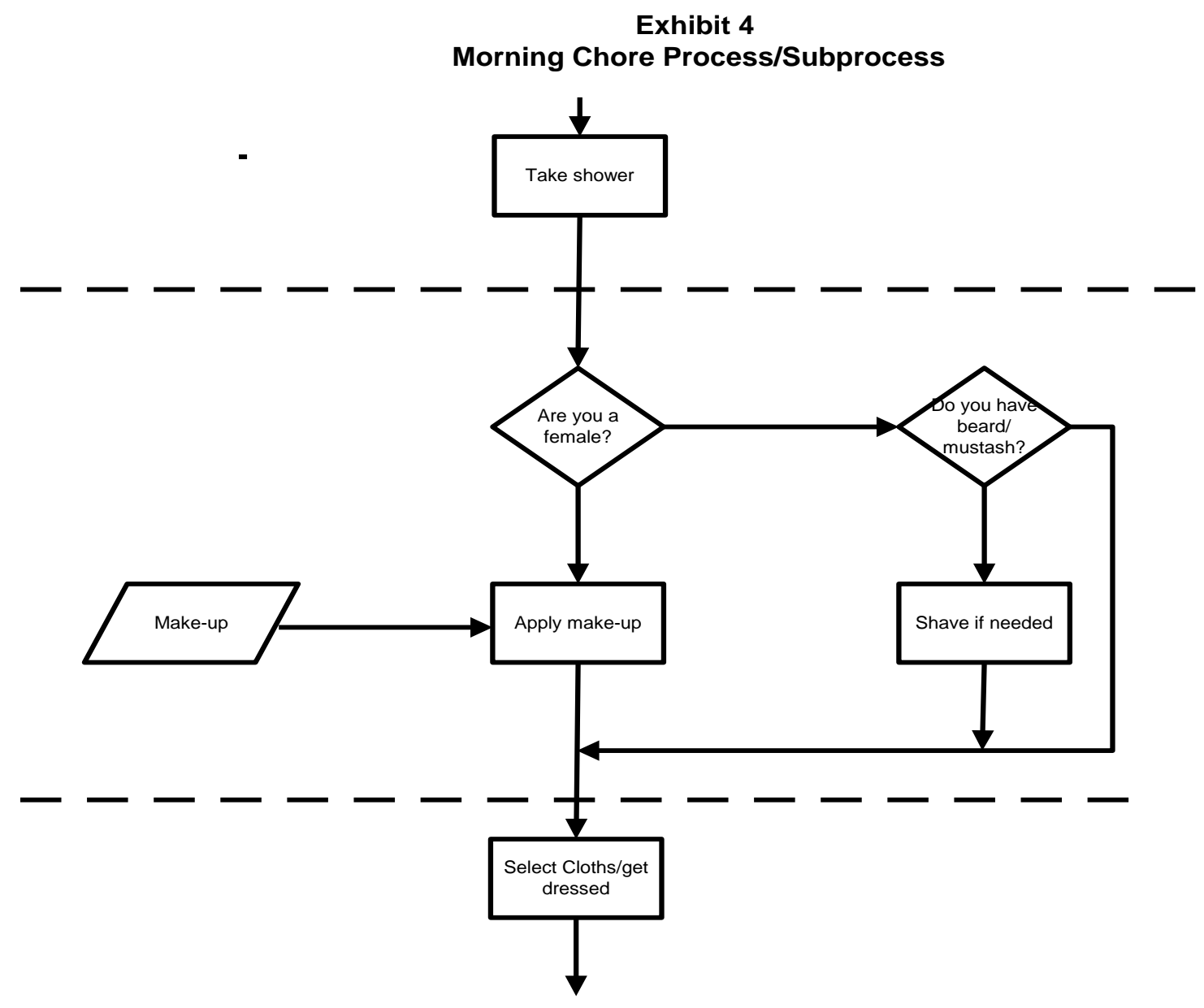

Exhibit 5

Receiving Process Description

$\mathrm{XYZ}$ Distribution is a medium size distributor of supplies to major manufacturing companies as well as to some job shops. The following is the description of what happens at $\mathrm{XYZ}$ when goods arrive at the warehouse.

When trucks stop at our loading dock, a warehouse supervisor examines the manifest/bill of lading (BOL) to determine if the shipment is intended for $X Y Z$. If the shipment does not belong to the company, the truck is turned away and the shipment will not be accepted. If the shipment is for $X Y Z$, the warehouse staff will stage the goods for 1st Stage Inspection. The warehouse supervisor then compares the staged goods to the BOL. If the number of boxes and pallets conform to the BOL, the warehouse supervisor signs the BOL. Otherwise, the discrepancies are noted on the $\mathrm{BOL}$ and the goods are set up for the 2nd Stage Inspection.

At the second stage, the goods re compared with the packing slip. Then, the goods are counted and any discrepancies are noted on the packing slip. Next,. the goods are inspected for damage. If the goods are satisfactory, they are staged for put-away. If any type of nonconformance was observe, the supervisor initiates what is called a nonconformace procedure. This process will aid in data gathering for improvement. 


\section{Second Assignment}

In the second assignment a business process is introduced. In this case it would be to the students' advantage to use a cost management process in this case an $\mathrm{ABC}$ project. This provides the instructor with a great opportunity in introducing the practical aspect of $\mathrm{ABC}$ not normally covered in undergraduate cost accounting textbooks.

The team may be assigned to prioritize activities or processes under analysis. Thus the concept of prioritizing and consensus matrix could be introduced at this time. In a consensus matrix the team would rank alternative processes first and then select a process that is a candidate for the $\mathrm{ABC}$ project.

Exhibit 5 describes the situation and Exhibit 6 is a suggested flowchart of the situation described.

\section{Third Assignment}

In this assignment the true power of process flowcharting is demonstrated. Consequently, this assignment requires some level of business maturity and understanding of the business process. Thus this could be an ideal project for senior/graduate students.

In today's corporations there is a major shift away from traditional accounting functions and towards strategic planning, internal consulting and process improvement. In this assignment the strategic role of management accountants in the development of a merger and acquisition process that can be used by companies is illustrated.

In the case description (a merger and acquisition in a utility company) it is emphasized that many staff members were involved in the creation of the process. The process is championed by a group of management accountants. Activities included in the processes would allow the company to (1) identify and evaluate business restructuring candidates and or alternatives; (2) negotiate a more favorable deal for the company; (3) close and implement the restructuring process more systematically and (4) save the company's resources which would have been wasted on a lengthy and inefficient process. Exhibit 7 shows in detail the steps that are typical in a business acquisition process.

The business combination strategies developed by the steering committee will drive the process into financial review path and business integration path. The financial review involves selection of the candidates for business combination, evaluation of the candidates, shortlisting them and eventually recommending the candidates for a more serious evaluation. If the steering committee found a candidate acceptable, then a due diligence review is ordered. At this stage it is normal for the parties to negotiate more specific points. Regulatory approval may be required for certain types of combinations. If required, approval is obtained at this stage of the process. Approval of the regulatory authorities will allow the parties of a given transaction to perform the final negotiation, close and record the deal in their respective books. When the closing is accomplished and the business combination is fully implemented, a post acquisition study should be required. The post acquisition study is performed to evaluate the merit of the actions taken throughout the process.

The integration path includes the steps for the development of an integration plan and the creation of the integration related issues. At this stage, various cultural and fitness of the business combination would be evaluated.

The flowchart follows the conventions appropriate for documentation of processes. The activities/steps are represented by a rectangle. A parallelogram represents the input/output of each activity or step. The starting point is determining the objectives based on the mission of the organization.

One of the advantages of process flow-charting is that it allows the systematic management of activities within an organization. Each of the activities in the flowchart could be further decomposed to a more refined activity or task. It is only through this decomposition that management could have all activities in check. This also would help management in the implementation process. For instance, Recording of Transaction activity on Exhibit 7 is decomposed further as described in Exhibit 8 - Recording Process for Business Combinations. In reading the later exhibit, it is assumed that the organization is utilizing an Enterprise Resource Planning (ERP) system for their transaction processing. 


\section{Exhibit 6}

Receiving Process

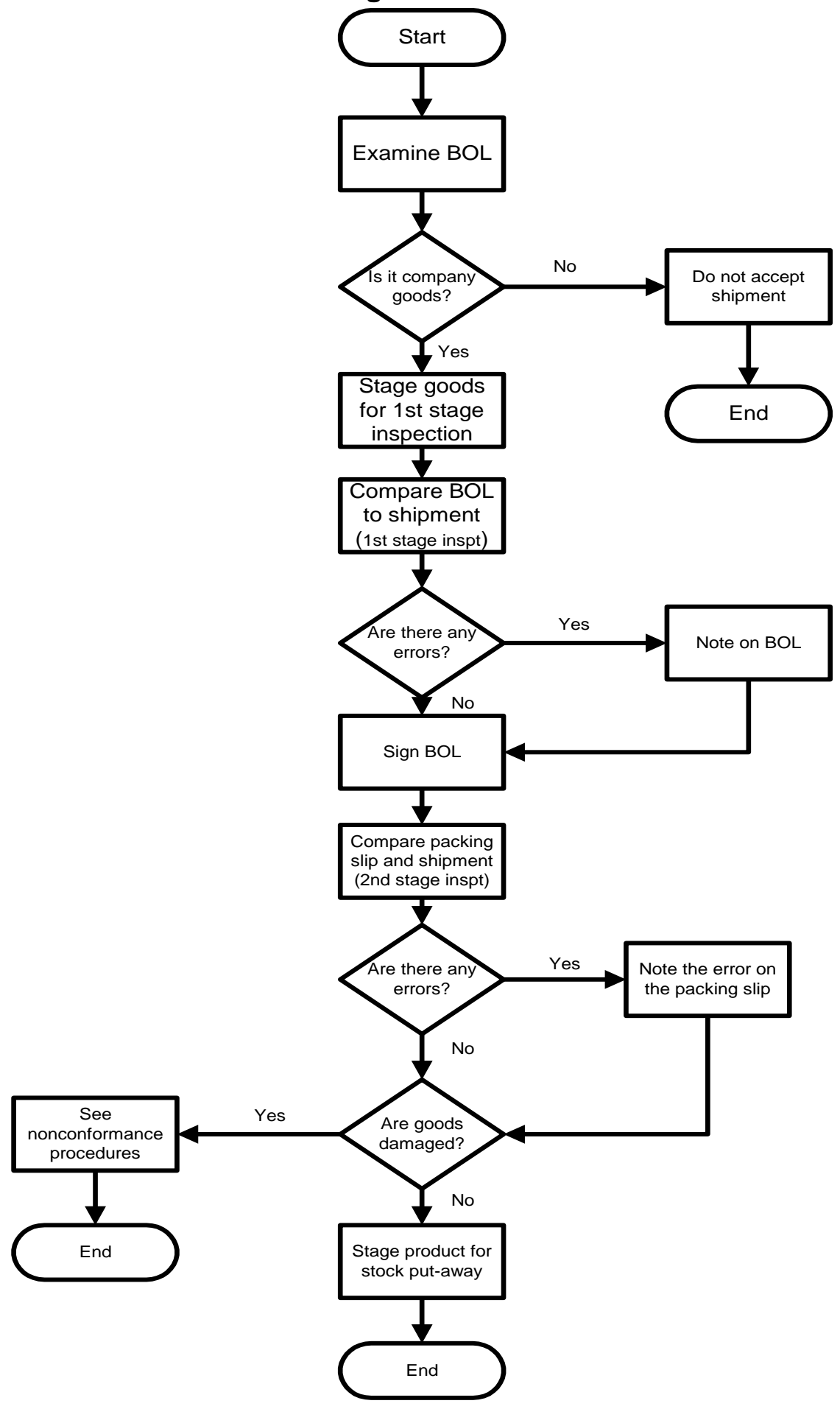




\section{Exhibit 7}

Business Combinations Process Flow

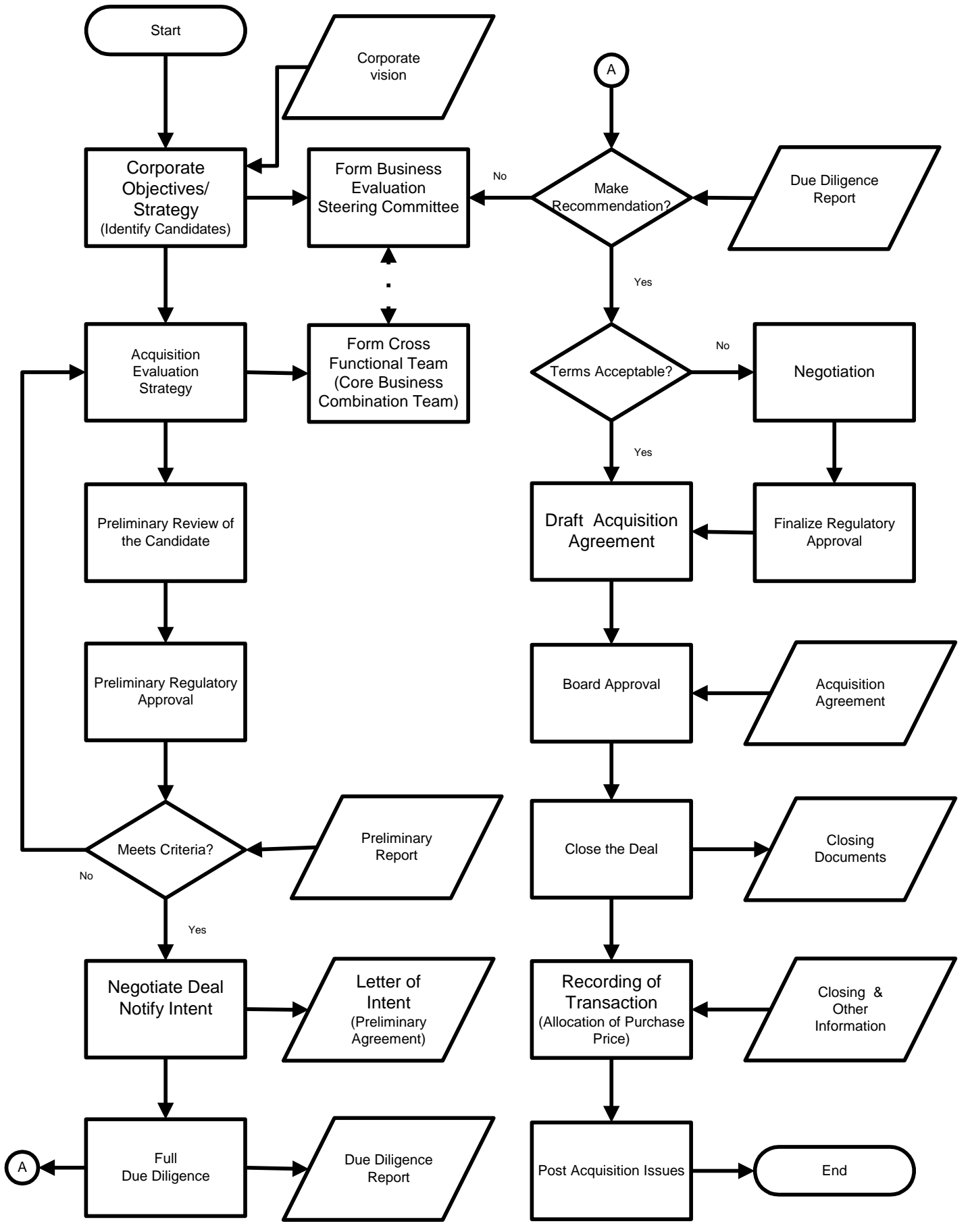


Exhibit 8

Recording Process forBusiness Combinations

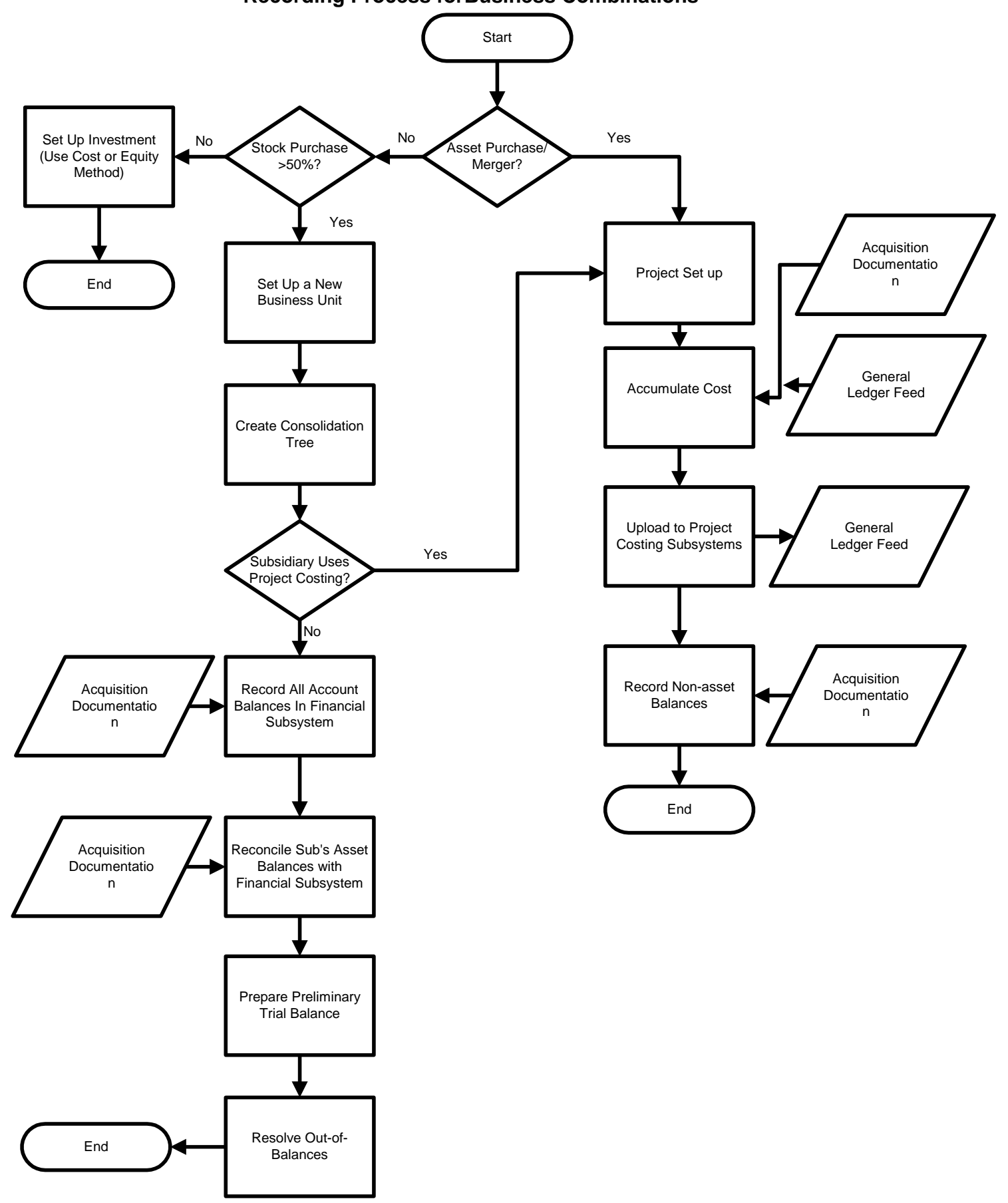




\section{Benefits of Process Flowcharting}

The benefits of process flowcharting cannot be quantifies. It appears benefits' level is correlated with the depth and breadth of the coverage of materials. The following are possible benefits:

- $\quad$ Allows critically study all activities and systematically manage them.

- Helps is evaluating alternative process solutions.

- $\quad$ Facilitates management of the processes such as measurement of activities, time and resources required and successful completion of the projects.

- $\quad$ Facilitates mapping of strategic actions.

- $\quad$ Adds value to a curriculum that eventually facilitates placement of more qualified graduates.

Several productivity tools are available to facilitate the teaching of process mapping. Microsoft Visio and ABC Flowcharting are among the more advanced software applications specifically designed for process flowcharting and process mapping. Students require minimum training to become relatively competent users of these packages. However, for schools that do not have such options, shareware software downloaded from the net could be a reasonable substitute for the flowcharting software. Microsoft Excel (Marshall, 2002) and Microsoft Word also provide minimal tools to satisfy the elementary needs of simple cases.

\section{Conclusion}

Traditional flowcharting mostly focuses on transactions processing thus, not sufficient to evaluate physical processes. Many organizations that are engaged in quality, improvement of their processes, reduction of their costs and enhancing their profit picture have used process flowcharting also referred to as process mapping. This paper suggests including process flowcharting skill into accounting program will add value to the product and make the graduates more marketable. Three different assignments are suggested for integration of skills at different level.

\section{Suggestions for Future Research}

This paper reports on integrating process flowcharting as a value-adding skill to a business curriculum in general and accounting information systems courses in specific. Future researchers should investigate and document the role that accountants play as members of interdisciplinary teams in designing and reengineering processes used in organizations. Results of such studies may provide the impetus for AIS educators to make a greater effort at including process analysis as an integral part of AIS courses.

\section{References}

1. Accounting Education Change Commission. Objectives of education for accountants: Position statement number one, Issues in Accounting Education (Fall): 307-312, 1990.

2. Albrecht, W. S. and R. J. Sack, Accounting Education: Charting the Course through a Perilous Future, Accounting Education Series, Volume 16, Sarasota, Florida: American Accounting Association, 2000.

3. American Accounting Association, Committee on the Future Structure, Content, and Scope of Accounting Education (The Bedford Committee), Future accounting education: Preparing for the expanding profession. Issues in Accounting Education (Spring): 168-195, 1986.

4. American Accounting Association, Mock Committee, Contemporary Approaches to Teaching Accounting Information Systems, Sarasota, Florida: American Accounting Association, 1987.

5. American Accounting Association, Teaching and Curriculum Section, Outcomes Assessment Committee, Report of the 1992-93 Outcomes Assessment Committee, 1993.

6. American Institute of Certified Public Accountants, Education Executive Committee, Education Requirements for Entry into the Accounting Profession. New York, NY: AICPA, 1988.

7. American Institute of Certified Public Accountants, Core Competency Framework For Entry Into the Accounting Profession, New York, N. Y., AICPA, 2000.

8. Arthur Andersen \& Co., Arthur Young, Coopers \& Lybrand, Deloitte Haskins \& Sells, Ernst \& Whinney, Peat Marwick Main \& Co., Price Waterhouse, and Touche Ross, Perspectives on Education: Capabilities for Success in the Accounting Profession (April), 1989. 
9. Bradford, M., Roberts, D., and Stroupe, G., Integrating Cross Functional Process Maps into the AIS Students' Toolset, Review of Business Information Systems, 5, 30-37, 2001.

10. Galloway, D., Mapping Work Processes, ASQC Quality Press Publications, Milwaukee, Wisconsin, 1994.

11. Hammer, M., The Supperefficient Company, Harvard Business Review 82-91, (September 2001).

12. Holder, W.W., and C.N. Mills, Pencils Down, Computers Up -The New CPA Exam, Journal of Accountancy 57-60, (March 2001).

13. Kaplan, R.S., and Norton, D.P., The Balanced Scorecard, Harvard Business School Press, 1996.

14. Lehman, M.W., Flowcharting Made Simple, Journal of Accountancy, 77-80, 2000.

15. Marshall, Jeffrey, More Complex, More Robust, Financial Executive, 44-45, (January/February 2002).

16. Moscove, S. A., Mark G. Somkin, and Nancy A. Bagranoff, Core Concepts of Accounting Information Systems, New York: Wiley, 2001.

17. Siegel, G, C.S. Kulesza, and J.E. Sorensen, Are You Ready for the New Accounting? Journal of Accountancy, 42 - 46, (August 1997). 
Notes 